\title{
Soil cover and landscape evolution in the Senegal floodplain: a review and synthesis of processes and interactions during the late Holocene.
}

\author{
S. FURIAN ${ }^{\mathrm{a}}$, A. O. MOHAMEDOU ${ }^{\mathrm{b}}$, C. HAMMECKER ${ }^{\mathrm{c}}$, J.-L. MAEGHT ${ }^{\mathrm{c}} \&$ L. BARBIERO $^{\mathrm{d}, \mathrm{e}}$. \\ aLaboratório de Pedologia, Departamento de Geografia, Universidade de São Paulo C.P. 8105, \\ 05508-900, São Paulo, Brazil, 'baculté des Sciences et Techniques de Nouakchott, B.P. 56, \\ Nouakchott, Mauritanie, ${ }^{\mathrm{c}}$ Institut de Recherche pour le Développement, Unité de Recherches 176, \\ Land Development Department, Office of Science for Land Development, Pahonyothin Road, \\ Chatuchak, Bangkok 10900, Thailand, 'Université Paul Sabatier (Observatoire Midi-Pyrénées) - \\ Géosciences Environnement Toulouse; 14 Av, Edouard Belin, F-31400 Toulouse, France and \\ eInstitut de Recherche pour le Développement - Géosciences Environnement Toulouse, F-31400 \\ Toulouse, France.
}

Correspondence: S. FURIAN. Email: furian@usp.br

Running title: Holocene landscapes in the Senegal Valley

\section{Summary}

The aim of this paper is to summarize the successive biological, pedological, hydrodynamic, geomorphological and geochemical processes that have occurred in the Senegal valley, and to describe how their interactions during the late Holocene conditioned soil cover formation and landscape evolution. Potential acidity accumulated as pyrite in the floodplain sediment during the last marine transgressions, and was expressed during the following regressions because of oxidation. Soil acidification was mitigated by the soil buffer capacity and by the interaction with the slightly alkaline continental freshwater of the river. Two pedogenetic transformation processes that resulted from the succession of acidic and neutral conditions, transformed un-ripe muds with pyrite (potential Acid Sulphate soil) to actual Acid Sulphate soils, and then to Vertisols. Geochemical modelling with PHREEQC quantitatively confirmed the feasibility of the processes involved. These two pedogenetic processes also controlled two independent salt accumulation processes: (i) the transformation of shell accumulation beds into gypsum layers and (ii) aeolian deflation and formation of clay dunes. The study shows that pedogenetic effects on alluvial material can lead to contrasting horizons that cannot be explained stratigraphically. It also shows that the presence of saline areas in the Senegal middle valley results from much more complex processes than a simple salt deposition during transgressions.

\section{Introduction}

Floodplains reflect the hydrogeomorphic environment of deposition and provide excellent records of past hydrologic and geomorphic conditions, as they preserve assemblages of flood derived sediments (Florsheim \& Mount, 2003; Hudson, 2003). However, post-depositional alteration, especially pedogenesis, often affects and changes the alluvial material. In order to understand floodplain soils and use them to interpret hydrological processes or palaeo-environmental conditions, it is essential, to discriminate pedogenetic from sedimentary structures. 


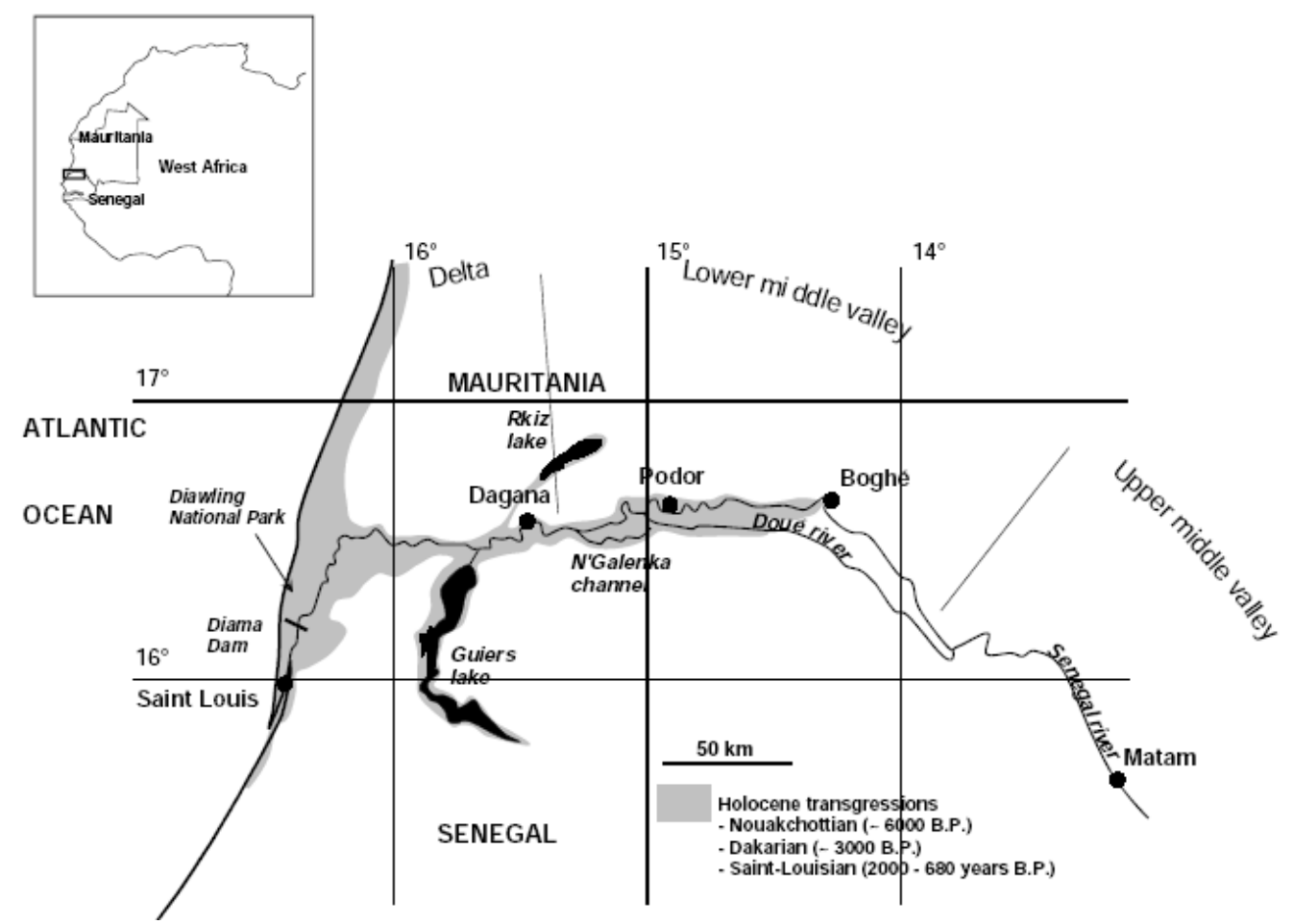

Figure 1 The Senegal River and the influence of marine transgressions during Holocene

Although the Senegal valley now has an unimpressive floodplain, its recent history was eventful, just like those of most of the West-African Rivers (Thorp \& Thomas, 1992). During the Quaternary, the sea transgressed several times into the valley (Faure et al., 1980). In the middle Holocene, soon after $6000 \mathrm{BP}$, the Nouakchottian transgression penetrated Pleistocene sand dunes, the shoreline reached about 1 to $3 \mathrm{~m}$ above present sea level (Barusseau et al., 2007; Sarr et al., 2008) and formed extensive shallow bays and lagoons in a large gulf as far inland as Boghé, located $380 \mathrm{~km}$ from the present coast (Figure 1). During the Taffolian regression, between 5000 and 3000 BP, the shoreline retreated westwards to $0.5 \mathrm{~m}$ below current sea level, and the Senegal River mouth was forced southwards (Michel, 1973). This period was terminated by a short transgression up to $2 \mathrm{~m}$ above sea level about 3000 BP, referred to as the Dakarian event. The Saint-Louisian transgression, when the sea reached levels about $1 \mathrm{~m}$ above sea level 2000 - 680 years B.P., was the last marine incursion.

Mangrove vegetation grew in the fluviomarine transgression environments. Around 500 years ago the sea and most the mangrove cover regressed from Boghé to the present Senegal delta, although remnants of the mangrove vegetation are still present along small watercourses in the delta. The sequence of transgression-regression cycles greatly contributed to the soil formation within the fluvial deposits of the Senegal valley, and pedogenesis obscured some sedimentary structures and stratification indicative of past flood-frequencies. The pedogenetic sequence led to contrasting soil horizons that look like alluvial layering and which have therefore been interpreted stratigraphically by many authors as indicating changes in the sedimentation regime of the river (Michel, 1973), whereas they may result from soil transformation processes. The objective of this paper is to summarize published data in order to integrate the processes that interacted to condition post-depositional soil formation and landscape evolution in the Senegal valley (Barbiero et al., 2004 $\&$ 2005). The soils of the Senegal floodplain can be considered as a chronosequence, with the most recent soils in the delta, and the most developed up-river at the border of the Holocene transgressions. Therefore, the present soil cover will be examined by considering successively the initial sedimentation, the formation of acid sulphate soils, their transformation into Vertisols, the control of aeolian deflation with clay dune formation and finally the consequences for the location 
and chemistry of present-day saline areas.

\section{Background description}

\section{Initial sedimentation}

The clay fraction mineralogy of the un-ripe mud in the lower Senegal delta is similar to the present day transported sediments at the river mouth (Gac \& Kane, 1986), and therefore is assumed to characterize the original river sediment before alteration by pedological processes. The clay fraction is composed of kaolinite, smectite and illite. The presence in the un-ripe mud of well-crystallized mica and the absence of interstratified minerals, in spite of some slightly weathered illite, suggests that the transformation of mica into smectite did not occur in the mud but was inherited from the source area.

There are significant vertical and lateral variations in the particle size distribution of the sand fraction in the floodplain along the valley. A bimodal distribution with peaks at $0.13 \mathrm{~mm}$ and 1.25 $\mathrm{mm}$ was described in Bell basin in the delta (Barbiero et al., 1998). Bimodal or unimodal coarse $(1.5 \mathrm{~mm})$, medium $(0.4 \mathrm{~mm})$ or fine $(0.13 \mathrm{~mm})$ grain-size distributions were observed at other sites along the valley (Barbiero et al., 2005).

\section{Potential acidity}

The mangrove vegetation that colonized the alluvium in the floodplain of the last transgression is a key point to understand the pedogenesis. The mangrove of the West African coast belongs to the Atlantic type and is characterized by a small number of species, including Rhizophora racemosa GFW. Mey., Rhizophora mangle L., Rhizophora harrissonii Lee., Avicennia africana P. Beauv. and Laguncularia racemosa Gaertn. (Giglioli \& Thornton, 1965; Marius \& Lucas, 1991). In the waterlogged environment around the mangrove roots, sulphur-fixing bacteria accumulated potential acidity as pyrite derived from inputs of seawater sulphate at each flood tide. The accumulation of pyrite required an open system supplied by the tides. The biological reduction of seawater sulphate produces dissolved alkalinity, which was removed from the system at ebb tide. At the same time the equivalent amount of potential acidity precipitates around the roots, as solid pyrite. This mineral can be considered as storing potential acidity as long as the reduced state was maintained. Pyrite is still observed at many places in the lower delta, where it appears as black mottles in the un-ripe mud and as framboidal crystals under SEM (Le Brusq et al., 1987). Pyrite contents are usually between 1 and $2 \%$, although values close to $5 \%$ of the soil mass have been reported (Seyni Boukar, 1983; Deckers et al., 1997). The impact of pyrite accumulated in the mangrove ecosystem can be observed in soils from the present Senegal delta up to Boghé, at about $380 \mathrm{~km}$ from the river mouth (Figure 1). The remnants mainly consist of small sesquioxidic 'iron pipes' that have formed by pyrite oxidation around the former pneumatorhizal roots of the mangrove vegetation.

\section{Formation of soils}

\section{Acid Sulphate soil}

The last regression, which occurred 500 years ago, encouraged oxidation in the soil profile, releasing acidity. The two main sets of pedological processes transformed the initial deposit into an Acid Sulphate soil were the physical ripening of the mud involving principally an irreversible loss of water (Pons \& Zonneveld, 1965), and a succession of chemical reactions responsible for the oxidation of iron minerals. The pyrite oxidation proceeded in several stages that are common in most acid sulphate soil formations. The first stage results in the formation of ferrous iron, sulphate and protons according to Equation (1):

$$
2 \mathrm{FeS}_{2}+7 \mathrm{O}_{2}+2 \mathrm{H}_{2} \mathrm{O} \rightarrow 2 \mathrm{Fe}^{2+}+4 \mathrm{SO}_{4}^{2-}+4 \mathrm{H}^{+}
$$


This reaction occurs at $\mathrm{pH}$ close to 7 and is relatively slow. When the $\mathrm{pH}$ drops below 4 , the rate of pyrite oxidation is increased by the catalytic oxidation of ferrous iron to ferric iron by the bacterium Thiobacillus ferroxidans. Thus

$$
4 \mathrm{Fe}^{2+}+\mathrm{O}_{2}+4 \mathrm{H}^{+} \text {T.ferroxidans } \rightarrow 4 \mathrm{Fe}^{3+}+2 \mathrm{H}_{2} \mathrm{O}
$$

The ferric iron then acts as a pyrite oxidant with the generation of more ferrous iron (Equation 3): this reaction is fast compared with Equation (1) (van Mensvoort \& Dent, 1998):

$$
\mathrm{FeS}_{2}+14 \mathrm{Fe}^{3+}+8 \mathrm{H}_{2} \mathrm{O} \rightarrow 15 \mathrm{Fe}^{2+}+2 \mathrm{SO}_{4}{ }^{2-}+16 \mathrm{H}^{+}
$$

Overall the oxidation of each mole of pyrite yields 4 moles of protons:

$$
\mathrm{FeS}_{2}+15 / 4 \mathrm{O}_{2}+7 / 2 \mathrm{H}_{2} \mathrm{O} \rightarrow \mathrm{Fe}(\mathrm{OH})_{3}+2 \mathrm{SO}_{4}{ }^{2-}+4 \mathrm{H}^{+}
$$

The protons then react with other soil minerals, releasing major constituents such as potassium, magnesium, aluminium, iron and silicon into the soil solution. Jarosite is a very common intermediary potassium-iron sulphate mineral, forming bright yellow mottles in acid sulphate soil profiles:

$$
12 \mathrm{FeS}_{2}+45 \mathrm{O}_{2}+30 \mathrm{H}_{2} \mathrm{O}+4 \mathrm{~K}^{+} \rightarrow 4 \mathrm{KFe}_{3}\left(\mathrm{SO}_{4}\right)_{2}(\mathrm{OH})_{6}+48 \mathrm{SO}_{4}{ }^{2-}+36 \mathrm{H}^{+}
$$

Jarsosite is stable in very acid conditions but is metastable at $\mathrm{pH}$ above 4 and ultimately it is hydrolysed to iron oxide, predominantly goethite and sometimes hematite (Dent, 1986; Van Breemen, 1976).

The chemical reactions above correspond to different stages in the development of the soil horizons from the bottom to the top of the profiles, as illustrated on Figure 2, 3 and 4 . In the following discussion, we used the terminology and definitions of Dent (1986).
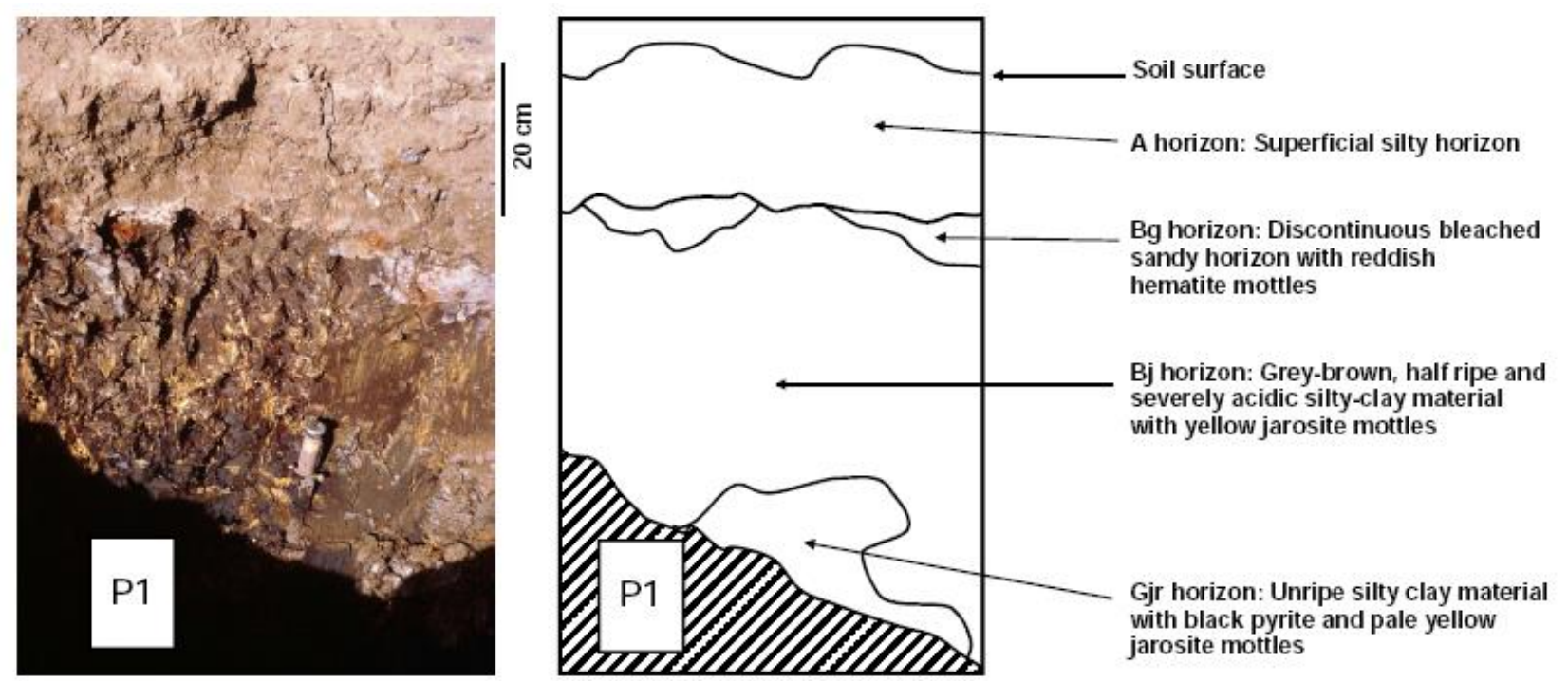

Figure 2 Silty clay Actual Acid Sulphate Soil (P1), with the initial appearance of thin discontinuous sandy horizon at about $20 \mathrm{~cm}$ depth. Jarosite appears as bright yellow mottles and oxidizes to goethite/hematite at the base of the sandy horizon 

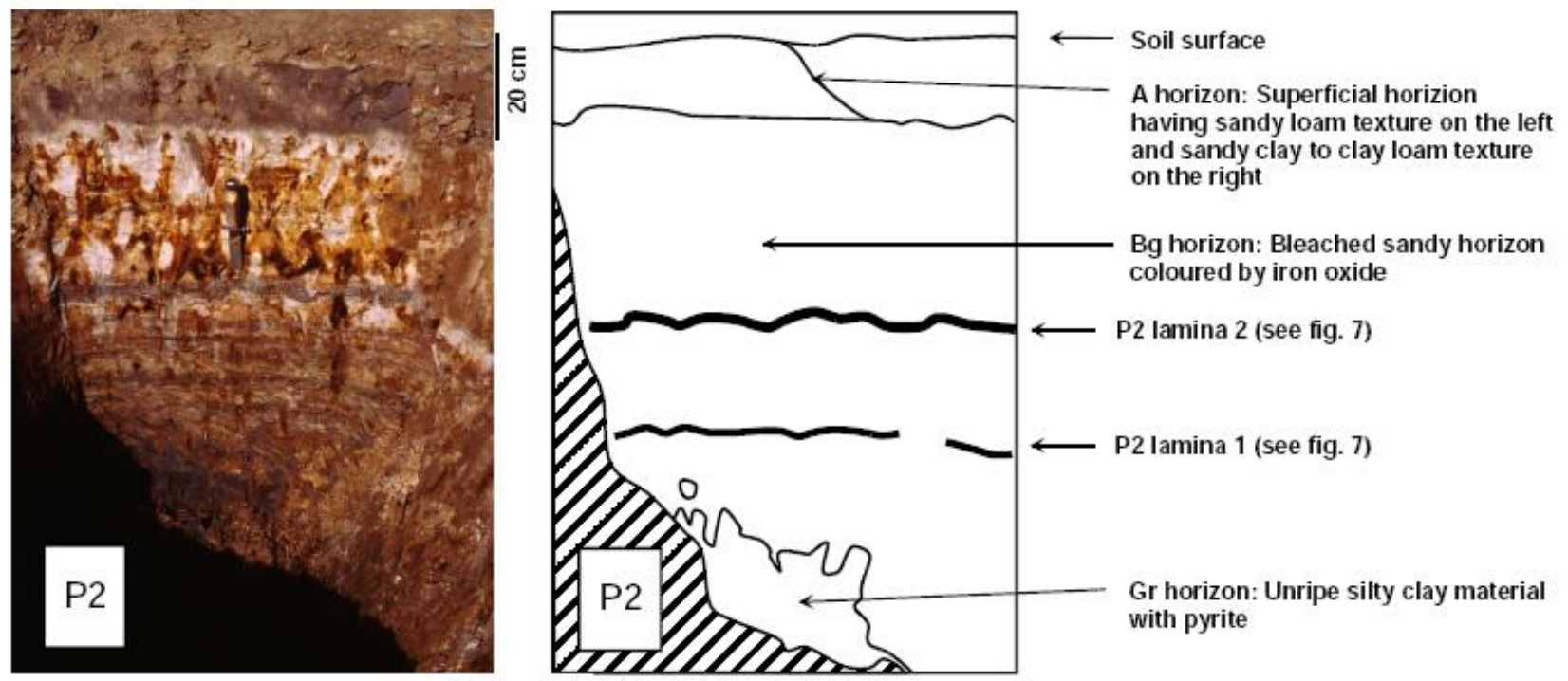

Figure 3 Sandy Acid Sulphate soil (P2). Beneath silty clay topsoil the sandy material with clay laminae extends from about $20 \mathrm{~cm}$ to the un-ripe mud with pyrite at about $1.1 \mathrm{~m}$ deep
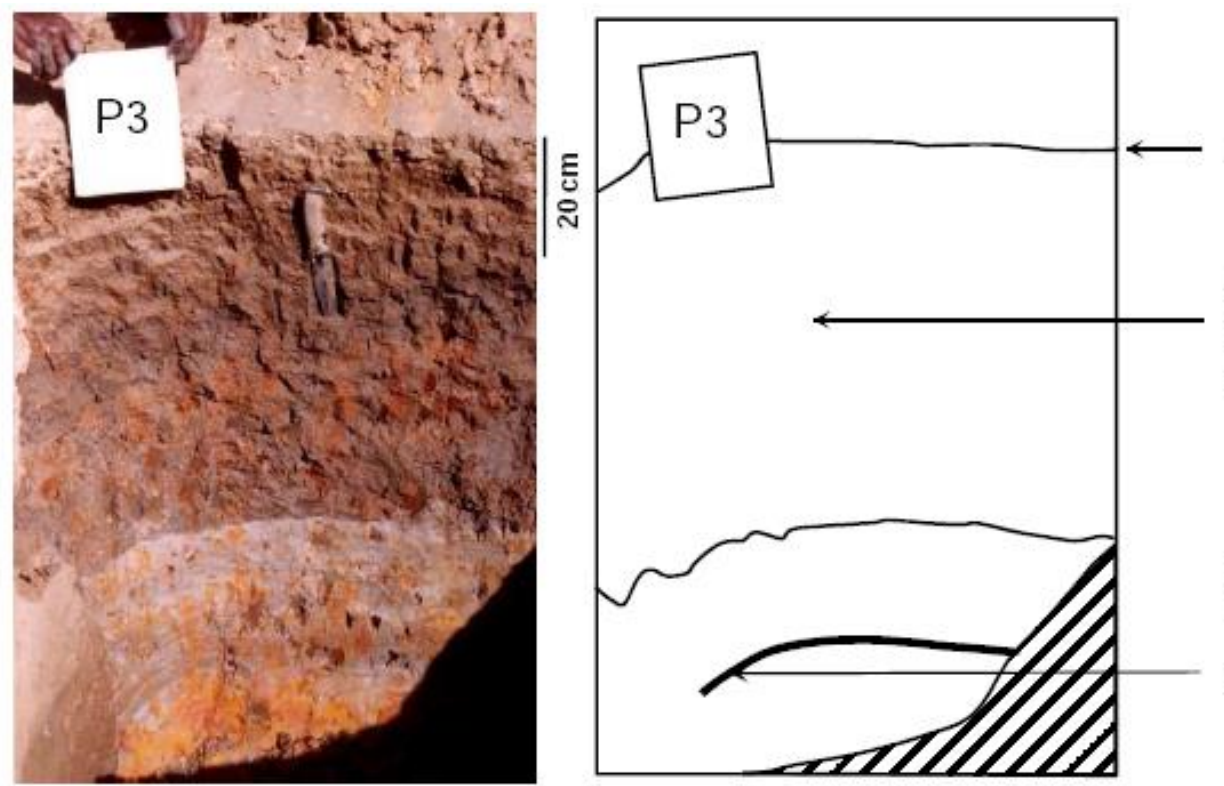

Soil surface

Superficial clay horizon with vertic properties and many mottles of goethite and hematite

Bleached sandy horizon coloured by iron oxide

P3 lamina 1 (see fig. 7)

Figure 4 Clay material with vertic properties overlying sandy material with clay laminae (P3)

\section{From Acid Sulphate Soil to Vertisol}

In the present day conditions in the Senegal floodplain, Acid Sulphate soils are not stable and they can be observed only in the lower delta. Up-river, they have been transformed into Vertisols (Barbiero et al., 2005). The strong acidity of the soil solution, following oxidation of pyrite, induced a series of chemical reactions related to acid neutralization by the alkalinity inherent in the soil, usually referred to as acid neutralizing capacity (ANC). This ANC is mainly provided by carbonates, exchangeable bases and easily weatherable silicates (Van Breemen \& Buurman, 2002). The first neutralisation of acidity is by the progressive dissolution of the shells and other carbonates:

$$
\mathrm{CaCO}_{3}+4 \mathrm{H}^{+}+\mathrm{SO}_{4}{ }^{2-} \rightarrow \mathrm{CaSO}_{4}, 2 \mathrm{H}_{2} \mathrm{O}+\mathrm{CO}_{2}
$$

This reaction was described in the Bell basin of the Diawling National Park, South Mauritania (Mohamedou et al., 2000) where carbonate layers usually comprised bivalve remains of Anadara senelis $L$. fragments or Tympanotonus fuscatus shells. The calcium released in the saline and 
sulphate-rich environment precipitated as centimetre scale gypsum nodules (Figure 5) as in Equation (6). The transformation of shell beds into gypsum layers was observed laterally along a soil transect of about 30 metres in the lower delta.
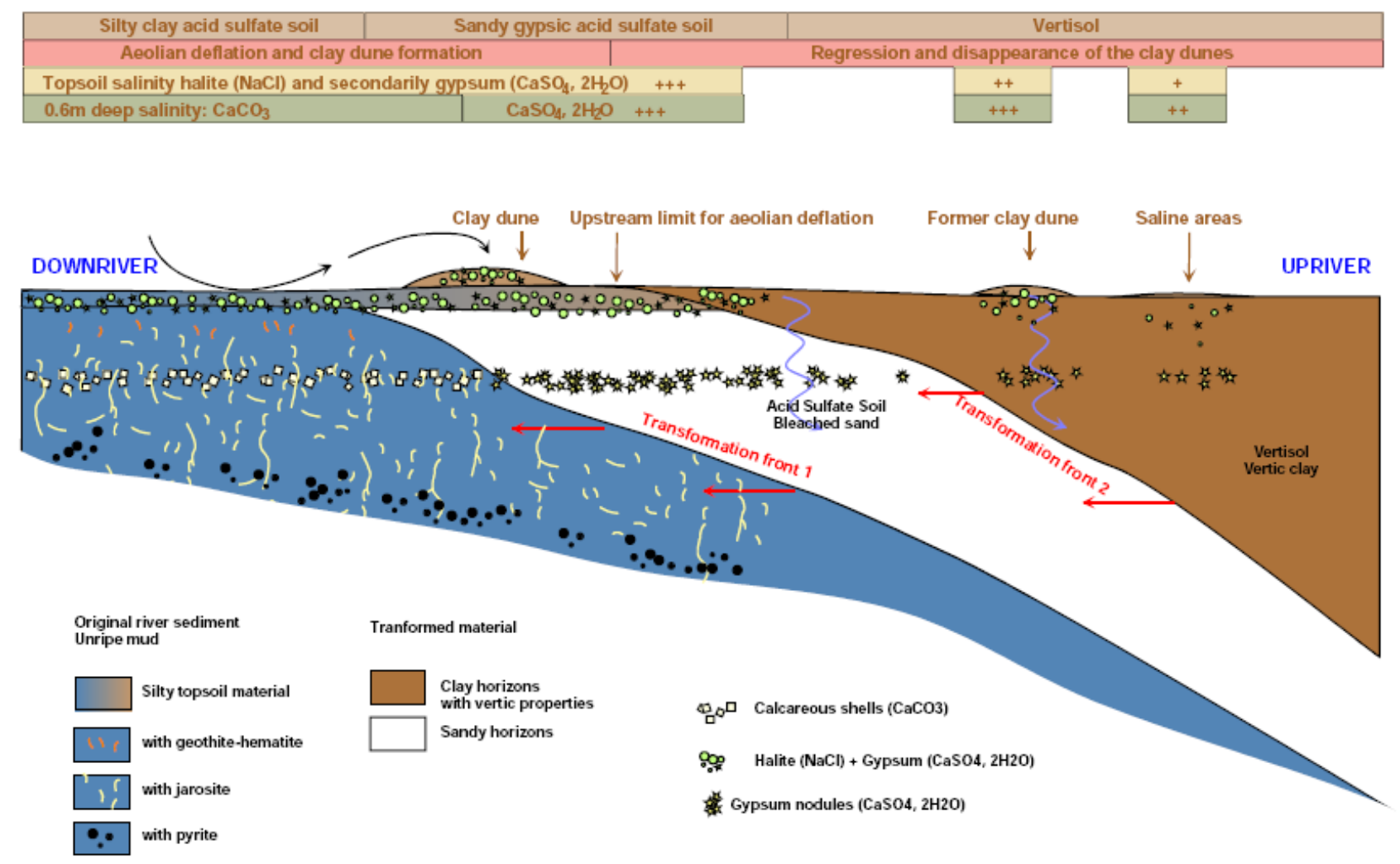

Figure 5 Schematic evolution of the Senegal floodplain sediments from the lower delta to the middle valley (about $400 \mathrm{~km}$ )

As well as the dissolution of the carbonates, acid neutralization is also effected by protonation of clay minerals. The resulting protonated clays are not stable and their crystalline structure is altered by $\mathrm{H}^{+}$at $\mathrm{pH}<4$ (Van Breemen, 1976). Protons penetrate the octahedral layers substituting for aluminium ions $\left(\mathrm{Al}^{3+}\right)$, which are released from the crystalline network and adsorbed on the clay surface. Consequently, $\mathrm{Al}^{3+}$ does not now bond the tetrahedral layers, releasing silica and metal ions, principally of aluminium, iron, magnesium and potassium, into the soil solution (Van Breemen et al., 1983; Van Breemen, 1988). The acid hydrolysis of aluminosilicate clays can contribute to $10 \%$ of the buffering of acid produced by the oxidation of pyrite (Dent \& Raiswell, 1982). The acid hydrolysis of clay minerals is responsible for the appearance of a bleached sandy horizon, resulting from the residual accumulation of quartz. The early stage of this soil horizon was detected at about 20-cm depth in profile P1 (Figure 2), where the oxidation of pyrite creates very acidic conditions. As this reaction slowly progresses downwards, a colourful soil profile develops, with a sandy overlying dark un-ripe mud with pyrite and jarosite mottles (Profile P2, Figure 3). This geochemical reaction of clay minerals dissolution and relative sand accumulation corresponds to the first pedological transformation front moving vertically downwards and also laterally downstream into younger alluvial deposit (Figure 5).

In acid sulphate solutions with large $\mathrm{Al}$ contents, the geochemistry of $\mathrm{Al}$ is controlled by sulphate, so that gibbsite and kaolinite are not the most stable phases (Bigham \& Nordstrom, 2000). Aluminium sulphate minerals were observed in the topsoil at several places along the Senegal floodplain where the acid soil solution concentrates (Le Brusq et al., 1987). Until the recent construction of Diama and Manantali dams that now regulate the river course, the Senegal River overflowed during the rainy season, and neutral or slightly alkaline continental freshwater 
infiltrated into the sandy or loamy horizons of the acid soil. The Senegal freshwater diluted and partially neutralized the acidity, and enabled the formation of kaolinite. At the contact between the fresh Senegal water and the acidic water rich in $\mathrm{Al}$, iron $(\mathrm{Fe})$ and silicon $(\mathrm{Si})$, kaolinite precipitated forming clay laminae in the sandy horizon (Figure 6). Mohamedou (2000) observed that the kaolinite in the clay laminae differed from that observed in the original river sediments, because it appeared slightly heat-resistant at the treatment at $500^{\circ} \mathrm{C}$ on X-ray diagrams, indicating that the kaolinite was precipitated in the laminae and was not a remnant directly inherited from the sediment.
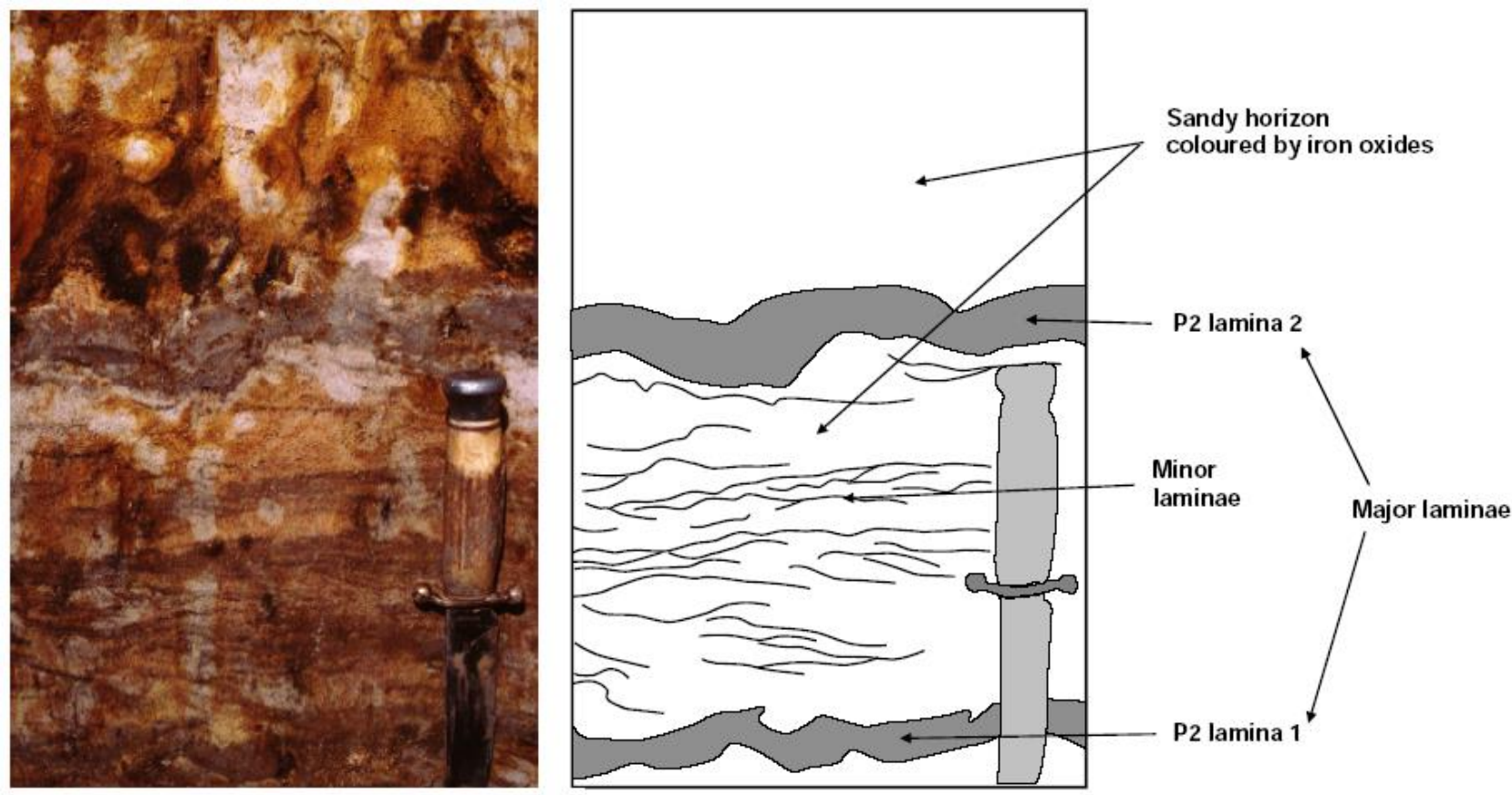

Figure 6 Detail of soil profile P2 showing clay laminae within sandy material

Progressively, the acid conditions were sufficiently neutralized by the large amounts of base cations present in the solution to allow smectite precipitation. By studying four successive clay laminae, along a 30-m short transect, Mohamedou (2000) has shown the progressive appearance of the smectite in the profiles, which first appeared as a plateau on X-ray diagrams, and then a peak became clearly apparent (Figure 7). Favre et al. (2002) identified large proportions of Fe in octahedral positions in the smectite, which appeared to be of an iron-beidellite type.

Eventually, the clay precipitation resulted in the formation of a superficial clay horizon, which starts on the right side of profile P2 (Figure 3) and thickens laterally and also acquires vertic properties. It results in the formation of profile P3 (Figure 4), where three main horizons are distinguished from the bottom to the top: (i) the un-ripe mud with pyrite and jarosite;, (ii) a sandy horizon with clay laminae and (iii) a clay horizon with vertic properties (wedge shaped aggregates). The clay neoformation is responsible for a second transformation front, which moves down-river transforming the sandy horizon. Up-river, the ratio of smectite:kaolinite increases indicating an increasing period of precipitation of smectite.

\section{Modeling the geochemical processes}

In order to evaluate quantitatively the feasibility of the geochemical processes invoked for the pedogenesis in the Senegal Valley sediments, we used PHREEQC (Parkhurst \& Appelo, 1999), a simulation of geochemical reactions, which has already been successfully used in pyritic acidic or alkaline alluvial conditions (Hammecker et al, 2009). The simulation has been run for a system open to water and $\mathrm{O}_{2}$ but without any export of other dissolved elements. Because of the time necessary for pedogenesis, the kinetics of the reactions have not been taken into account and the simulations have been taken through to equilibria (when ionic product $\mathrm{Q}$ is equal to solubility 
product $K$ ). In the simulation the initial un-ripe mud was considered being composed of kaolinite, traces of calcite $(0.01 \mathrm{~mol})$, illite and $5 \%$ by mass of pyrite and was put in contact with seawater (Table 1). The system has then been oxidized by progressive addition of 0.45 moles of oxygen gas, showing an increase in (i) the soil acidity until reaching $\mathrm{pH} 2.9$ and (ii) of the redox potential, until reaching a value around $\mathrm{p} E 6.8$ (Figure 8). At the same time, the evolution of the mineralogy has been calculated according to the respective dissociation equations and solubility product $(\mathrm{K})$ of the minerals involved in this reaction.

Table 1 : Composition of the seawater and of the river Senegal, used in the simulation with PHREEQC

\begin{tabular}{lcccccccc}
\hline & $\mathrm{pH}$ & $\mathrm{Ca}$ & $\mathrm{Na}$ & $\mathrm{K}$ & $\mathrm{Mg}$ & $\mathrm{Cl}$ & Alkalinity & SO4 \\
\cline { 3 - 8 } & & \multicolumn{7}{c}{$\mathrm{mmol} / 1$} \\
\hline Seawater & 8.1 & 10.4 & 468 & 9.97 & 53.3 & 546 & 2.34 & 28.1 \\
River Senegal & 7.28 & 0.115 & 0.1 & 0.06 & 0.115 & 0.06 & 0.61 & 0.003 \\
\hline
\end{tabular}

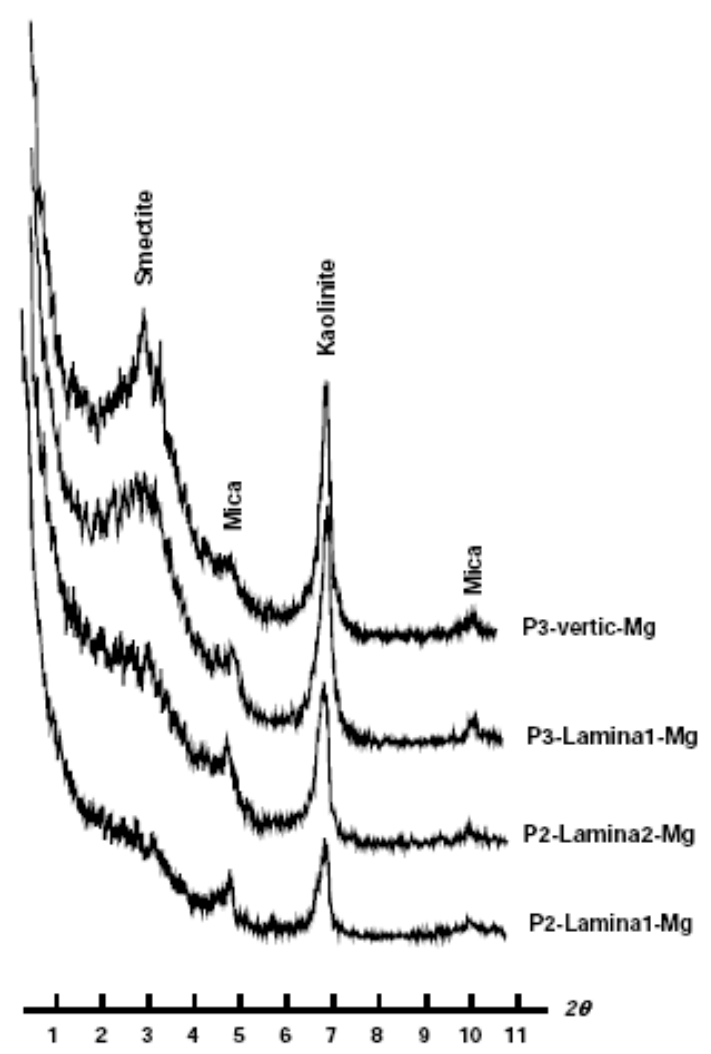

Figure $7 \mathrm{X}$-ray diffraction traces for Mg-saturated clay fractions of laminae showing the gradual evolution of smectite (modified from Barbiero et al., 2005) 

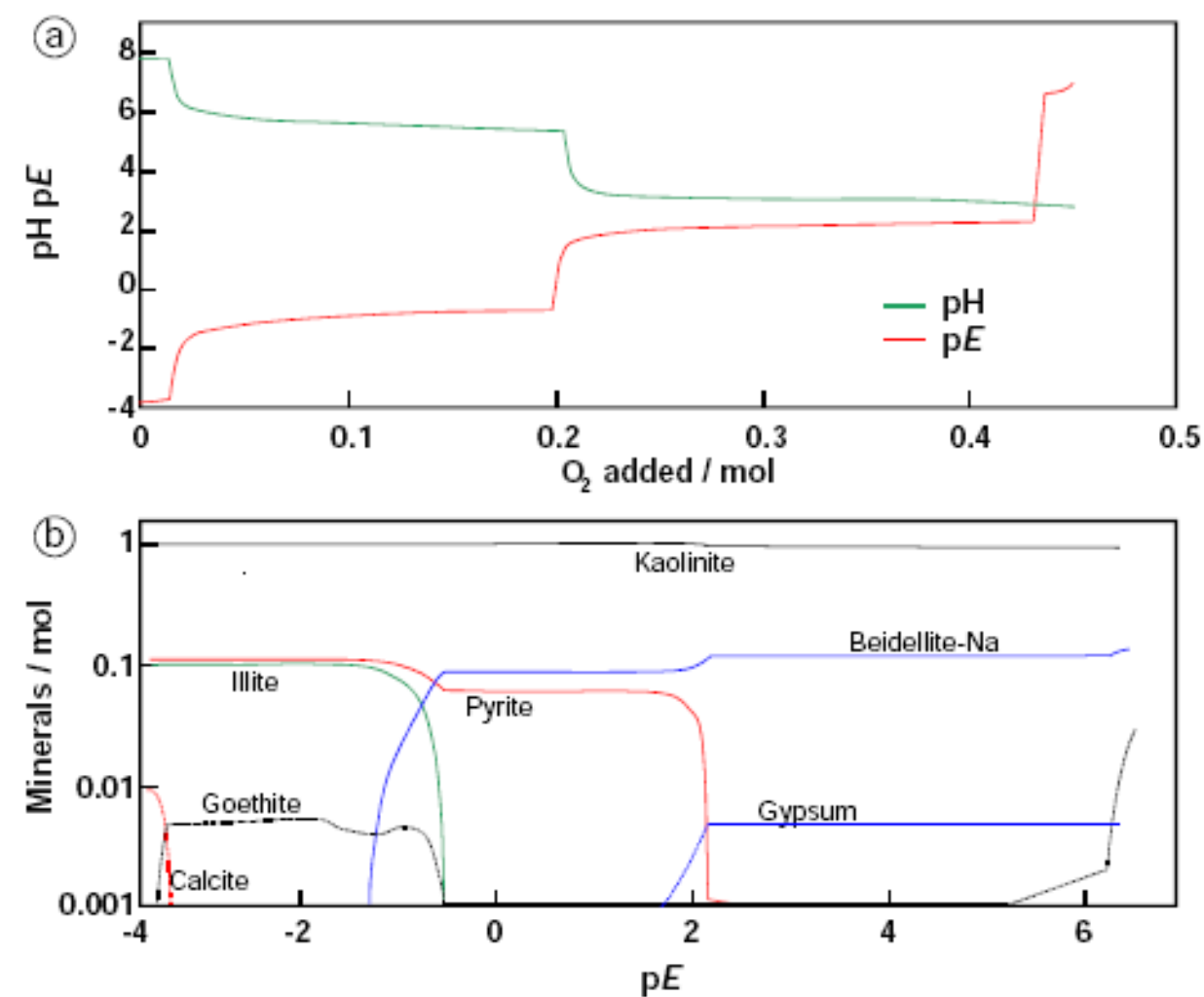

Figure 8 Simulation with the PHREEQC model of the evolution of a, the $\mathrm{pH}$ and $\mathrm{p} E$ (redox) values in soil solution and $b$, the mineralogy during the oxidation and dewatering of un-ripe pyritic mud

The results (Figure 8) show a complete dissolution of calcite, pyrite and illite and a partial dissolution of kaolinite. On the other hand, goethite, gypsum and beidellite crystallized from this solution in significant quantities. In fact, because of the large molecular weight of beidellite $(0.389$ $\mathrm{kg}$ per mol) compared with kaolinite $(0.258 \mathrm{~kg}$ per mol), the beidellite formed during this reaction reaches $24 \%$ of the total mass. Beidellite crystallized at the expense of illite and kaolinite, but was limited by the amount of calcite that affects the evolution of the acidity in the soil solution. However the simulation did not show a general precipitation of jarosite, despite its importance as a reacting mineral. If run without allowing precipitation of goethite, jarosite crystallized at the end of the simulation when the Fe(II) was completely oxidized. Therefore, iron was apparently the limiting element for jarosite precipitation. In soil profiles, local chemical micro-sites, with specific compositions (higher organic matter and iron content) caused by the ancient roots of Rhizophora with probable greater organic matter and iron contents, probably determine geochemical conditions that are more suitable for jarosite crystallization.

Though the concentration of magnesium $(\mathrm{Mg})$ in seawater is much greater than that of $(\mathrm{Ca})$, the associated mineralogy in the soil does not show Mg-rich minerals, because these are highly soluble in the range of $\mathrm{pH}$ of these soils and $\mathrm{Mg}$-silicates are usually associated with very alkaline environments (Furquim et al., 2008, 2010). 


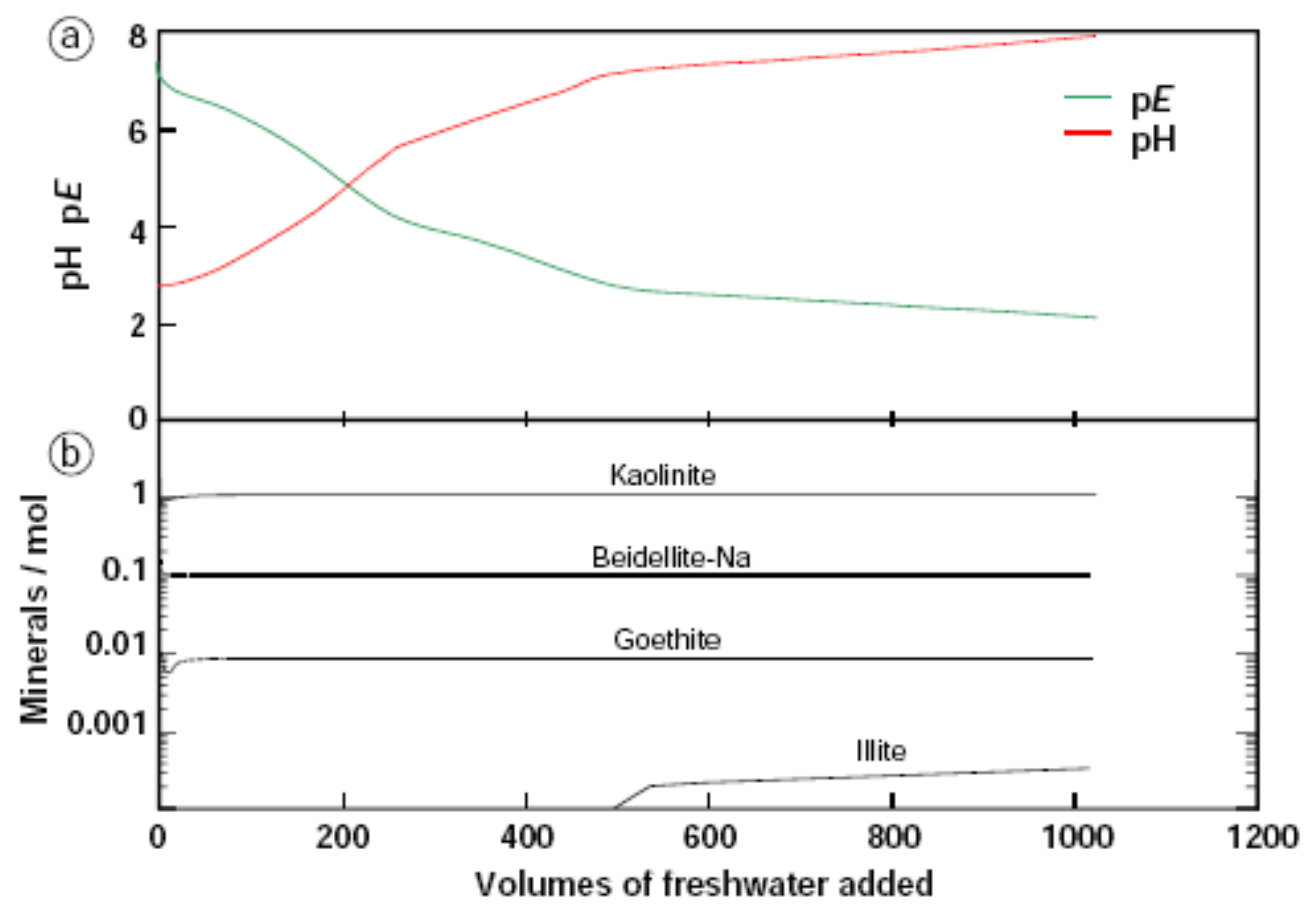

Figure 9 Simulation with the PHREEQC model of the evolution of a, $\mathrm{pH}$ and $\mathrm{p} E$ of the soil solution and $b$, the mineralogy with progressive fresh water flooding (river Senegal) of Acid Sulphate soil

When fresh water from the river Senegal was added to this solution the mineralogy remained unchanged, but $\mathrm{pH}$ increased towards slightly alkaline values $(\mathrm{pH}$ 7.8) and concomitantly $\mathrm{p} E$ decreased from 6.8 to 1.84 (Figure 9). This simulation shows that the reactions and the element quantities involved in the oxidation of sediments of the valley of river Senegal are compatible with the hypothesis of the formation of soils enriched in 2:1 clay minerals with vertic properties. The proportion of 2:1 minerals should increase in the soil in successive wetting-dehydration cycles. Additional input data, such as the number of cycles and the seasonal variability in the river water composition would be required to take into account successive wetting-dehydration cycles in the numerical simulation.

As a consequence, both of the transformation fronts with the appearance of a sandy bleached horizon and then the clay precipitation, led to a contrasted soil profile with a vertic clay horizon abruptly overlying a sandy horizon which in turn was over an un-ripe mud with pyrite. The vertic clay and sandy horizons thickened progressively and totalled about $1 \mathrm{~m}$ in the delta (soil profile P3) to more than $6 \mathrm{~m}$ in the N'Galenka region near Podor, about $200 \mathrm{~km}$ inland (Zanolin et al., 1997; Barbiero et al., 2005).

The clay and sandy horizons have previously been attributed to changes in sedimentation during and after the Nouakchottian transgression. Michel (1973) attributed the sandy horizon to fluviomarine re-deposition of Pleistocene Ogolian (12000-18000 BP) sand dunes during the Taffolian regression (Deckers et al., 1997). Recent studies revealed, however, that these contrasting soil horizons cannot be interpreted stratigraphically. The grain size distribution of the sand fraction indicates a pedological origin for the contrast between the clay material and the sand located below. Along the valley, the grain-size distribution varied substantially between the different profiles (Figure 10), but it was always similar vertically within each profile on either side of the abrupt discontinuity between the clay horizon with vertic properties and the sandy horizon below (Barbiero et al., 2005). This consistent granulometric uniformity is unlikely if the soil profiles resulted from different sedimentation episodes, as the different sedimentation regimes required for the deposition of these contrasted materials (sandy then clay) would result in different sand size distributions. On the other hand, the sand-grain size distribution would be maintained through the pedological 
transformations as these mainly involve changes (destruction and neoformation) in the clay fraction.
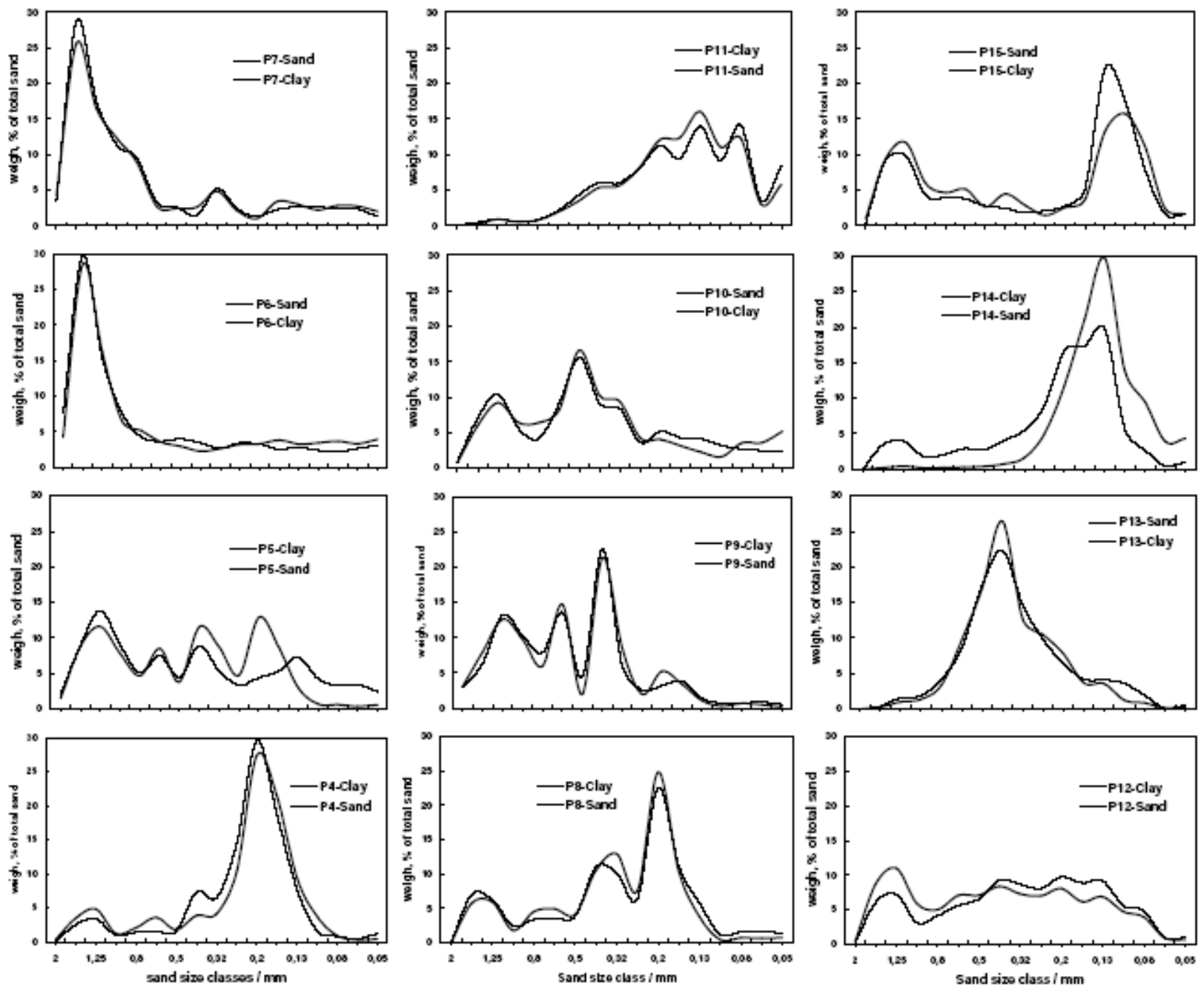

Figure 10 Distribution of sand size fractions on either side of textural discontinuities between vertic clay and bleached sandy horizons in profiles along the Senegal valley (modified from Barbiero et al., 2005)

\section{Other interacting processes}

\section{Control of aeolian deflation}

The process of aeolian deflation and clay dune (or lunette) formation has been studied by numerous authors in saline alluvial valleys and particularly in the deltas of West African rivers, such as in Senegal and Casamance (Maymard, 1952; Tricart, 1954; Vieillefon, 1967; Michel, 1973; Mougenot, 1982; Mohamedou et al., 1999). Clay dunes are a few metres wide with vertical dimensions of a few decimetres, but they can reach several kilometres long. They are not really clays but usually have loamy-sand textures, and are called clay dunes in opposition to true sand dunes. They develop by seasonal deflation from pan floors in saline conditions and by sediment accumulation along small watercourses. As the pan dries, salt concentration increases and induces the clay in the mud of the pan floor to flocculate into a soft powder, consisting of silt and sand-size particles, which are vulnerable to wind transport. The phenomenon of soft powder formation is caused by the rapid crystallization of salts such as gypsum near the soil surface.

The environmental conditions favouring the formation of clay dunes are restricted. They require a prevailing wind during the dry season, temporary saline pan conditions, and loamy-sand texture sediment of the pan floor and soil hydraulic properties favouring upwards capillary flow 
from groundwater. Because of these restrictions, clay dunes are frequently used for reconstitution of palaeo-environments (Price, 1963; Bowler, 1973; Lancaster, 1978; Goudie \& Thomas, 1984; Youg \& Evans, 1986; Thomas et al., 1993; Marker \& Holmes, 1995).

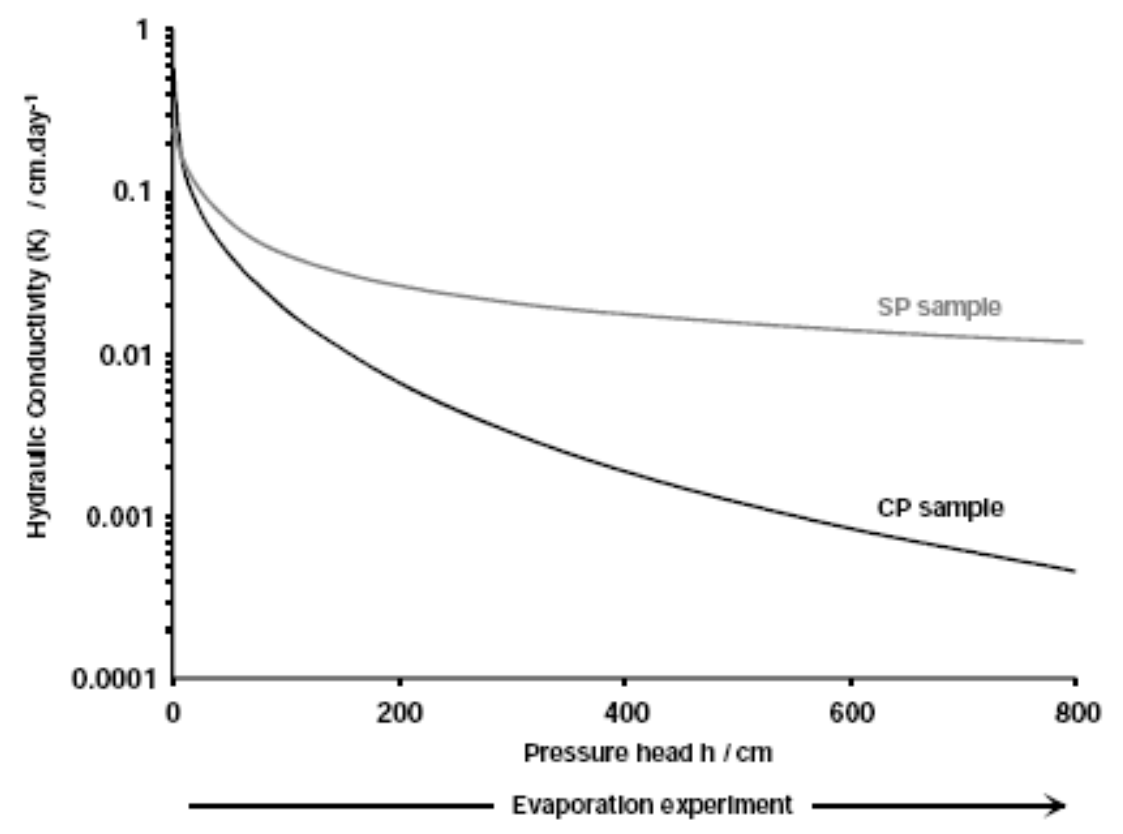

Figure 11 Changes in the hydraulic conductivity during the outflow experiment carried out on soil blocks with soft powder (SP) and centimetre scale platelets (CP) surfaces

In the Senegal delta, abrupt changes in the surface structure can be observed, shifting from deflatable soft powder (SP) to stable centimetre-scale platelets (CP). These contrasting structures form at the beginning of the dry season when the water table is still close to the topsoil. Mohamedou (1998) suspected that it resulted from lateral changes in soil salinity, but no correlation was established between topsoil structure and soil conductivity, measured with an electromagnetic induction device (EM38, Geonics Ltd, Ontario, Canada). On the other hand, Mohamedou showed that the lateral change in the topsoil structure closely matched the increase in surface clay (soil profile P2) caused by the early stage of the second transformation. In the soft powder soil (SP) the clay content of the surface horizon was about $15 \%$, and it increased abruptly to $30 \%$ in the surface associated with platelets $(\mathrm{CP})$. Mohamedou therefore concluded that the change in topsoil texture was probably responsible for the different structures related to specific hydrodynamic behaviour.

An outflow experiment was carried out to derive the soil hydraulic properties controlling water flow and solute transport in unsaturated soils (Wind, 1968). The objective was to characterize differences in hydraulic conductivity $(\mathrm{K})$ with volumetric water content $(\theta)$ and pressure head $(\mathrm{h})$ in $\mathrm{CP}$ and SP types of topsoil. The experiment was carried out on two soil blocks, sampled about $5 \mathrm{~m}$ apart, on either side of a lateral change between SP and CP surfaces (Wade, 2000). Results indicated that the saturated hydraulic conductivity (Ks) was greater in the CP than in the SP sample. However, the decrease of hydraulic conductivity with decreasing water content was less sharp for SP sample than for CP sample, so that hydraulic conductivity for SP was greater in most of the range of water contents prevailing in the field (Figure 11).

These results indicate that for a same potential evaporation flux (controlled by the meteorological conditions and the seasonal periodicity), the capillary rise of the saline solution from the shallow groundwater would reach the surface more easily in soils with SP than CP surfaces. Consequently evaporation and hence salt crystallization would take place more readily near the soil surface in SP soils. In CP soils most of the salt precipitates at an average depth of $3 \mathrm{~cm}$ below the soil surface. In the SP soils, the superficial salt crystallization led to the formation of a soft powder, vulnerable to deflation. In the second case (CP), deeper salt crystallization favoured platelets that are much less vulnerable to wind erosion. 
Wade (2000) concluded that the changes in the topsoil texture induced by the second transformation front prevent aeolian deflation, and control the process of clay dune formation in the valley. Therefore, aeolian deflation and clay dune formation occurred only on the Acid Sulphate soils and did not occur on the Vertisols. The transformation front from Acid Sulphate soils into Vertisols is progressing downriver. It started at the limit of the last transgression, close to the city of Boghé, and can be observed now in the lower delta. The remains of former clay dunes can still be observed up-river, in between Vertisols. These former clay dunes are now degrading and disappearing.

\section{Consequences for salinity and salt distribution}

Saline areas have been attributed to the incorporation of marine salts in the sediments during the last marine transgression (Boivin et al., 1998). However, this cannot explain totally their shape, location and geochemical features. In the middle valley, the saline areas follow a regular pattern and are distributed as strips about 100-200 m wide and several kilometres long, without regular direction. These saline strips are intersected by more recent geomorphic structures such as creek meanders, indicating that the salt distribution is ancient. It is related to the former geomorphology, and appears not to result from a recent remobilization of relict marine salts in the soil (Barbiero et al., 2001). The study of the type of salinity reveals the presence of various chemical compositions, within the same saline area, and down individual soil profiles over short vertical distances $(20$ to $30 \mathrm{~cm})$. The juxtaposition of these chemical differences cannot arise one from the other by simple concentrationdilution processes, and such a salt distribution require different sources and vectors of salinization.

Barbiero et al. (2004) proposed a model based on field observations along the chronosequence of the Senegal valley in order to explain the distribution, shape, topography and chemistry of the saline areas. In the middle valley they consist of former clay dunes that developed before the transformation of Acid Sulphate soils into Vertisols. The salinity was mainly NaCl, with secondary $\mathrm{CaSO}_{4}$ also present, in agreement with the topsoil salinity in Acid Sulphate soils. The clay dunes were deposited mainly on the leeward sides of former meandering watercourses occupied by the mangrove vegetation, which acted as wind-break. Therefore, clay dunes were elongated structures fringing the former channels. Transformation into Vertisols stopped aeolian deflation and clay dune formation. Afterwards, clay dunes were progressively degraded but the salt was incompletely leached from the soil. In contrast, gypsum was formed by the transformation of shell beds at about 0.6-0.8-m deep at the first transformation front. This gypsum was leached in most places by fresh water floods from the river, except below the former clay dunes, where the percolating soil solutions reached chemical saturation close to the topsoil, and thus were less reactive towards the deeper gypsum layers. Therefore, former clay dunes are detected nowadays as saline areas with salts from two sources (i) aeolian $\left(\mathrm{NaCl}\right.$ and secondarily $\left.\mathrm{CaSO}_{4}\right)$ and (ii) from transformation of shell beds into gypsum layers.

\section{Conclusions}

The recent evolution of the sediments in the Senegal valley is a good example of the connections between biological (pyrite accumulation), hydrological (sea regression and river flooding), pedological (development of Acid Sulphate soil and transformation into Vertisol), geomorphological (aeolian deflation and clay dune formation) and geochemical processes (expression of accumulated acidity and salt accumulations) in the development of a soil system. One of the lessons to be drawn from the Senegal valley is that pedological processes can be fast and powerful under extreme geochemical conditions, in this case, high acidity. Here, the initial acidic conditions and their subsequent modification by river flooding are the driving forces behind the soil formation from un-ripe mud to Vertisol, via Acid Sulphate soil, obliterating the inherited stratification in the floodplain deposits.

As the conditions for clay dune formation are restricted, they are frequently used for the 
reconstruction of palaeo-environments. Interruptions of the sedimentation of clay dune are generally attributed to changes in the climatic or hydrological conditions. The present study shows that transformations in the topsoil can result in a pedogenic interruption of the aeolian deflation without any other environmental changes. Further studies could focus on the role of the West African climatic gradient on the distribution of these soil forming processes in other floodplains, such as those of the Sine-Saloum, Gambia, and Casamance.

\section{Acknowledgements}

This work was partially supported by a research grant from Agence Francophone pour l'Enseignement Supérieur et la Recherche (AUPELF-UREF), awarded to Abdallahi Ould Mohamedou. We thank the Fundação de Amparo à Pesquisa do Estado de São Paulo (FAPESP) for grant $\mathrm{n}^{\circ} 2009 / 53524-1$ that helped to complete this work.

\section{References}

Barbiero, L., Mohamedou, A.O. \& Caruba, R. 1998. Influence de la maturation des sols de mangrove sur la déflation éolienne et la formation de dunes argileuses dans le delta du fleuve Sénégal. Comptes Rendus de l'Académie des Sciences Paris, 327, 115-120.

Barbiero, L., Cunnac, S., Mané, L., Laperrousaz, C., Hammecker, C. \& Maeght, J.L. 2001. Salt distribution in the Senegal middle valley. Analysis of a saline structure on planned irrigation schemes from N'Galenka creek. Agricultural Water Management, 46, 201-213.

Barbiero, L., Ould Mohamedou, A., Laperrousaz, C., Furian, S. \& Cunnac, S. 2004. Polyphasic origin of salinity in the Senegal delta and middle valley. Catena, 58, 101-124.

Barbiero, L., Ould Mohamedou, A., Roger, L., Furian, S., Aventurier, A., Rémy, J.C. et al. 2005. The origin of Vertisols and their relationship to Acid Sulfate Soils in the Senegal Valley. Catena, 59, 93-116.

Barusseau, J.P., Vernet, R., Saliège, J.F. \& Descamps, C. 2007. Late Holocene sedimentary forcing and human settlements in the Jerf el Oustani - Ras el Sass region (Banc d'Arguin, Mauritania). Géomorphologie, Relief, Processus, Environnement, 1/2007, on line http://geomorphologie.revues.org/index634.html.

Bigham, J.M. \& Nordstrom, D.K. 2000. Iron and aluminium hydroxysulfate minerals. In: Sulfate Minerals. Crystallography, Geochemistry, and Environmental Significance (eds C.N. Alpers, J.L. Jambor, \& D.K. Nordstrom), pp. 351-403. Reviews in Mineralogy and Geochemistry 40, Mineralogical Society of America, Washington, D.C.

Boivin, P., Favre, F. \& Maeght, J.L. 1998. Les sols de la moyenne vallée du fleuve Sénégal: caractéristiques et évolution sous irrigation. Etude et Gestion des Sols, 5, 235-246.

Bowler, J.M. 1973. Clay dunes: their occurrence, formation and environmental significance. Earth Science Reviews, 9, 315-338.

Deckers, J., Dondeyne, S., Vandekerckhoven, L. \& Raes, D. 1997. Major soils and their formation in the West African Sahel. In: Irrigated Rice in the Sahel: Prospects for Sustainable Development (eds K.M. Miézan, M.C.S. Wopereis, M. Dingkuhn, J. Deckers \& T.F. Randolph), pp. 23-35. Warda/Adrao, Dakar, Senegal.

Dent, D. 1986. Acid sulphate soils: a baseline for research and development. ILRI Publication 39, ILRI, Wageningen, The Netherlands.

Dent, D.L. \& Raiswell, R.W. 1982. Quantitative model to predict the rate and severity of acid sulfate development: a case study, the Gambia. In: Proceedings of the Bangkok symposium on Acid Sulfate Soils (eds H. Dost \& N. Van Breemen), pp. 73- 95. ILRI Publication 31, ILRI, Wageningen, The Netherlands,

Faure, H., Fontes, J.C., Hebrard, L., Monteillet, J. \& Pirazzoli, P.A. 1980. Geoidal changes and shore-level tilts along Holocene estuaries: Sénégal river area, West Africa. Science, 210, 421423. 
Favre, F., Tessier, D., Abdelmoula, M., Génin, J.M., Gates, W.P. \& Boivin, P. 2002. Iron reduction and changes in cation exchange capacity in intermittently waterlogged soil. European Journal of Soil Science, 53, 175-193.

Florsheim, J.L. \& Mount, J.F. 2003. Changes in lowland floodplain sedimentation processes: predisturbance to post-rehabilitation, Cosumnes River, CA. Geomorphology, 56, 305-323.

Furquim, S.A.C., Graham, R.C., Barbiero, L., Queiroz Neto, J.P. \& Vallès, V. 2008. Mineralogy and genesis of smectites in an alkaline-saline environment of Pantanal wetland, Brazil. Clays and Clay Minerals, 56, 580-596.

Furquim, S.A.C., Graham, R.C., Barbiero, L., Queiroz Neto, J.P. \& Vidal-Torrado, P. 2010. Soil mineral genesis and distribution in a saline lake landscape of the Pantanal wetland, Brazil. Geoderma, 154, 518-528.

Gac, J.Y. \& Kane, A. 1986. Le fleuve Sénégal : I. Bilan hydrologique et flux continentaux de matières particulaires à l'embouchure. Sciences Géologiques Bulletin, 39, 99-130.

Giglioli, M.E.C. \& Thornton, I. 1965. The mangrove swamps of Keneba, Lower Gambia River Basin. I. Descriptive notes on the climate, the mangrove swamps and the physical composition of their Soils. Journal of Applied Ecology, 2, 81-103.

Goudie, A.S. \& Thomas, D.S.G. 1984. Lunettes in southern Africa. Journal of Arid Environments, 10, $1-12$.

Hammecker, C., van Asten, P., Marlet, S., Maeght, J.-L. \& Poss, R. 2009. Simulating the evolution of soil solutions in irrigated rice soils in the Sahel. Geoderma, 150, 129-140.

Hudson, P.F. 2003. Floodplains: environment and process. Geomorphology, 56, 223-224.

Lancaster N., 1978. The pans of the southern Kalahari, Botwana. Geographical Journal, 144, 8198.

Le Brusq, J.Y., Loyer, J.Y., Mougenot, B. \& Carn, M. 1987. Nouvelles paragenèses à sulfates d'aluminium, de fer, et de magnésium, et leur distribution dans les sols sulfatés acides du Sénégal. Science du Sol, 25, 173-184.

Marius C. \& Lucas, J. 1991. Holocene mangrove swamps of West Africa: Sedimentology and Soils. Journal of African Earth Sciences, 12, 41-54.

Marker, M.E. \& Holmes, P.J. 1995. Lunettes dunes in the northeast Cape, South Africa, as geomorphic indicators of palaeoenvironmental changes. Catena, 24, 259-273.

Maymard, J. 1952. Les sols du pseudo-delta du Sénégal. Mission d'aménagement du Sénégal, Bulletin $\mathrm{n}^{\circ} 5$, Centre ORSTOM de Dakar Hann, Senegal.

Michel, P. 1973. Les bassins des fleuves Sénégal et Gambie. Etude géomorphologique. Mémoire ORSTOM 63. Paris, France.

Mohamedou, A.O. 1998. Contribution à l'étude de l'environnement du Parc National du Diawling (Mauritanie). Eaux-Sols-Végétation. PhD thesis, Univ. Nice-Sophia Antipolis.

Mohamedou, A. O. 2000. Evolution pédogénétique des sols de mangrove de la vallée du fleuve Sénégal et phénomènes associés. Post-Doctoral report, Univ. Nouakchott, Mauritania.

Mohamedou, A.O., Aventurier, A., Barbiéro, L., Caruba, R. \& Valles, V. 1999. Geochemistry of clay dunes and associated pan in the Senegal delta (Mauritania). Arid Soil Research \& Rehabilitation, 13, 265-280.

Mougenot, B. 1982. Etude pédologique de la cuvette de N'Tiagar (Partie Nord), delta du fleuve Sénégal. Research report, Dakar-Hann ORSTOM Centre, Senegal.

Parkhusrt, D.L. \& Appelo, C.A.J. 1999. User's guide to PHREEQC (version 2) - A computer program for speciation, batch reaction, one-dimensional transport, and inverse geochemical calculations. Water-Resources Investigations Report 99-4259, USGS, Colorado.

Pons, L.J. \& Zonneveld, I.S. 1965. Soil ripening and soil classification. ILRI Publication 13, ILRI, Wageningen, The Netherlands.

Price, W.A. 1963. Physicochemical and environmental factors in clay dune genesis. Journal of Sedimentary Petrology, 33, 766-778.

Sarr, R., Sow, E.H. \& Sarr, B. 2008. Holocene marine intrusions in Retba and Mbawane lakes (Senegal) evidenced by ostracod faunas. Revue de Micropaléontologie, 51, 327-338. 
Seiny Boukar, L. 1983. Etude pédologique de la cuvette de N'Der, lac de Guiers (Région du fleuve Sénégal). Research Report, Dakar-Hann ORSTOM Centre, Senegal.

Thomas, D.S.G., Nash, P.A., Shaw, P.A. \& Van der Post, C. 1993. Present day lunette sediment cycling at witpan in the arid southwestern Kalahari desert. Catena, 20, 515-527.

Thorp M. \& Thomas M. 1992. The timing of alluvial sedimentation and floodplain formation in the lowland humid tropics of Ghana, Sierra Leone and western Kalimantan (Indonesian Borneo). Geomorphology, 4, 409-422.

Tricart, J. 1954. Influence des sols salés sur la déflation éolienne en basse Mauritanie et dans le delta du Sénégal. Revue de Geomorphologie Dynamique, 5, 124-132.

Van Breemen, N. 1976. Genesis and solution chemistry of acid sulfate soils in Thailand. Agricultural Research Report 848, Centre for Agricultural Publishing and Documentation, Wageningen, The Netherlands.

Van Breemen, N. 1988. Effects of seasonal redox processes involving iron on the chemistry of periodically reduced soils. In: Iron in Soils and Clay Minerals (eds J.W. Stucki, B.A. Goodman \& U. Schwertmann), pp. 797-809. D. Reidel, Dordrecht.

Van Breemen, N., Mulder J. \& Driscoll, C.T. 1983. Acidification and alkalinization of soils. Plant \& Soil, 75, 283-308.

Van Breemen, N. \& Buurman, P. 2002. Soil Formation, 2nd edn. Kluwer Scientific Publishers, Dordrecht.

Van Mensvoort, M.E.F. \& Dent, D.L. 1998. Acid sulfate soils: methods for assessment of soil degradation. In: Advances in Soil Science (eds R. Lal, W.H. Blum, C. Valentine \& B.A. Stewart), pp. 301-335. CRC Press, Boca Raton, USA.

Vieillefon, J. 1967. Sur l'existence de bourrelets éoliens ou "lunettes" dans les mangroves de Casamance. In: Préhistoire et étude du Quaternaire - Congrès Panafricain (eds Comité Panafricain de Préhistoire et de l'Etude du Quaternaire, Dakar, Senegal), pp. 436-441. Chambery, France,

Wade, M.A. 2000. Détermination des paramètres hydrodynamiques de deux types de sol du delta du fleuve Sénégal, simulation des transferts hydrosalins : application au phénomène de déflation éolienne. Mémoire d'ingénieur Institut des Sciences de la Terre, UCAD, Dakar, Senegal.

Wind, G.P. 1968. Capillary conductivity data estimated by a simple method. In: Water in the Unsaturated Zone, Vol. 1 (eds P.E. Rijtema \& H. Wassink). Proceedings of the Wageningen Symposium, 19-23 June 1966. Int. Assoc. Sci. Hydrol. Publ. (IASH), Gentbrugge, The Netherlands and UNESCO, Paris.

Young J.A. \& Evans R.A. 1986. Erosion and deposition of fine sediments from playas. Journal of Arid Environment, 10, 103-116.

Zanolin, A., Tchani, J., Barbiero, L., Boivin, P. \& Descloitres, M. 1997. Apport de la méthode électrique pour la reconnaissance hydrogéologique et l'étude des variations superficielles en zone sédimentaire subsaharienne. In: Géophysique des Sols et des Formations Superficielles (eds BRGM, INRA, ORSTOM \& UPMC), pp. 173-178, Bondy, France. 